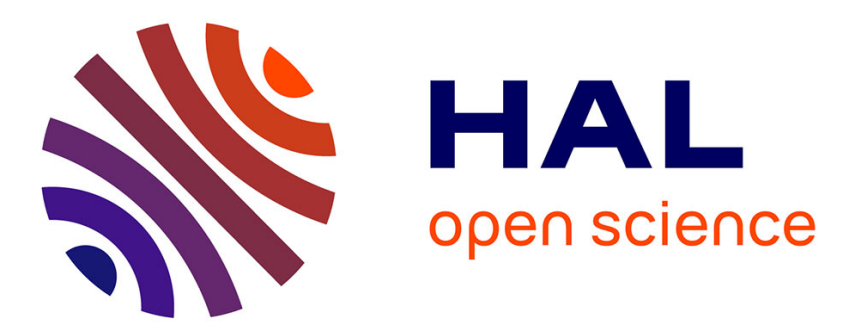

\title{
Bienzymatic-based electrochemical DNA biosensors: a way to lower the detection limit of hybridization assays
} Murielle Rochelet-Dequaire, Naima Djellouli, Benoit Limoges, Pierre Brossier

\section{To cite this version:}

Murielle Rochelet-Dequaire, Naima Djellouli, Benoit Limoges, Pierre Brossier. Bienzymatic-based electrochemical DNA biosensors: a way to lower the detection limit of hybridization assays. Analyst, 2009, 134, pp.349-353. 10.1039/b816220d . hal-00449664

\section{HAL Id: hal-00449664 https://hal.science/hal-00449664}

Submitted on 22 Jan 2010

HAL is a multi-disciplinary open access archive for the deposit and dissemination of scientific research documents, whether they are published or not. The documents may come from teaching and research institutions in France or abroad, or from public or private research centers.
L'archive ouverte pluridisciplinaire HAL, est destinée au dépôt et à la diffusion de documents scientifiques de niveau recherche, publiés ou non, émanant des établissements d'enseignement et de recherche français ou étrangers, des laboratoires publics ou privés. 


\title{
Bienzymatic-based electrochemical DNA biosensors: a way to lower the detection limit of hybridization assays
}

\author{
Murielle Rochelet-Dequaire, ${ }^{\text {a }}$ Naïma Djellouli, ${ }^{a}$ Benoît Limoges, ${ }^{b}$ Pierre Brossier $^{a}$
}

\author{
Received (in $X X X, X X X)$ Xth $X X X X X X X X X 200 X$, Accepted $X$ th $X X X X X X X X X 200 X$ \\ ${ }_{5}$ First published on the web $X$ th $X X X X X X X X X 200 X$ \\ DOI: 10.1039/b000000x
}

The use of the alkaline phosphatase (AP) as enzyme label and the amplification of its analytical response with a diaphorase (DI) secondary enzyme were investigated in an electrochemical hybridization assay involving arrays of carbon screen-printed DNA biosensors for the sensitive quantification of an amplified 406-base pair human cytomegalovirus DNA sequence (HCMV DNA). For this 10 purpose, PCR-amplified biotinylated HCMV DNA targets were simultaneously bound to a monolayer of neutravidin irreversibly adsorbed on the surface of the electrodes and hybridized to complementary digoxigenin-labeled detection probes. The amount of hybrids immobilized on the electrode surface was labeled with an anti-digoxigenin AP conjugate and quantified electrochemically by measuring the activity of the AP label through the hydrolysis of the electroinactive $p$-aminophenylphosphate (PAPP) substrate into the $p$ aminophenol (PAP) product. The intensity of the cyclic voltammetric anodic peak current resulting from the oxidation of PAP into $p$ -

15 quinoneimine (PQI) was related to the number of viral amplified DNA targets present in the sample, and a detection limit of $10 \mathrm{pM}$ was thus achieved. The electrochemical response of the AP label product was further enhanced by adding the diaphorase enzymatic amplifier in the solution. In the presence of the auxiliary enzyme DI, the PQI was reduced back to PAP and the resulting oxidized form of DI was finally regenerated in its reduced native state by its natural substrate, NADH. Such bienzymatic amplification scheme enabled a 100-fold lowering of the HCMV DNA detection limit obtained with the monoenzymatic system.

\section{Introduction}

In the past decade, the detection of PCR-amplified DNA 25 sequences through their hybridization has become an increasingly implemented method in the diagnosis of pathogenic organisms present in clinical, food and environmental samples. In this context, DNA biosensors coupling the inherent specificity of DNA recognition reactions with the sensitivity of transducers 30 have been the subject of intense research activity due to their ability to provide the sequence-specific information in a more rapid and simplistic manner as compared to the traditional hybridization assays. ${ }^{1}$ Various transduction methods have been used to monitor nucleic acid binding events, including 35 fluorescence, ${ }^{2}$ surface plasmon resonance, ${ }^{3}$ piezoelectric, ${ }^{4}$ and electrochemical techniques. ${ }^{5}$ Among them, electrochemistry has drawn great attention over other conventional methods for decentralized screening of infectious agents owing to its high sensitivity, low cost, rapid response, small dimensions, low 40 power requirements, and compatibility with microfabrication technology. Different strategies for the detection of the DNA recognition event based on the intrinsic electroactivity of the nucleic acids, ${ }^{6}$ redox-active hybrid indicators, ${ }^{7}$ metal complexes, ${ }^{8}$ gold nanoparticles, ${ }^{9}$ or enzyme labels ${ }^{10}$ have been reported so far.

45

${ }^{a}$ Laboratoire Interactions Muqueuses Agents Transmissibles, EA-562 Facultés de Médecine et Pharmacie, 7 Boulevard Jeanne d'Arc, 21000 Dijon, France Fax : + 333802936 04; Tel:+33 3803932 54; E-mail: 50 Murielle.Dequaire@u-bourgogne.fr

${ }^{b}$ Laboratoire d'Electrochimie Moléculaire, UMR CNRS 7591, Université Paris 7-Denis Diderot, 2 place Jussieu, 75251 Paris Cedex 05, France Fax : +331442776 25; Tel:+33157278789; E-mail: limoges@univparis-diderot.fr
However, due to the intrinsic signal amplification provided by biocatalytic reactions, enzyme labels were involved in most of the amperometric detection schemes of DNA hybridization. The 60 transduction of the enzyme activity into an electrochemical signal can result from either the catalytic conversion of a substrate to an electroactive product or a redox-mediated electrocatalytic transformation. This has been demonstrated with various enzyme labels such as horseradish peroxidase (HRP), ${ }^{10,11}$ alkaline 65 phosphatase (AP), ${ }^{12}$ PQQ-dependent glucose dehydrogenase, ${ }^{13}$ bilirubine oxidase, ${ }^{14}$ glucose oxidase ${ }^{15}$ and esterase $2^{16}$ which allowed nano-to femtomolar detection limits of nucleic acids in solution to be achieved.

70 Recently, we investigated neutravidin-coated carbon screenprinted DNA sensors based on a mediated HRP label and showed that PCR-amplified human cytomegalovirus (HCMV) DNA fragments could be determined at the picomolar level. ${ }^{11 \mathrm{c}}$ Molecular diagnosis of HCMV is commonly based on the PCR 75 coupled with a detection method due to the low abundance of viral DNA in biological samples. Despite their undeniable efficiency, the PCR amplification techniques are expensive, timeconsuming and not free from error (false positive). Hence, to provide an alternative for PCR methods while meeting the 80 demands of clinical diagnostics for sensitivity and costeffectiveness, the amperometric response of enzymatic DNA sensors must be undoubtedly further enhanced. A large variety of strategies have been developed for amplifying enzyme-based amperometric responses including wiring the enzyme to an ${ }^{85}$ electron conducting polymer, ${ }^{10}$ the use of multiple enzymes per binding events, ${ }^{17}$ metallization catalyzed by an enzyme, ${ }^{18}$ recycling or accumulating the reaction product ${ }^{12 \mathrm{~d}}$ and the coupling of two enzyme labels through substrate or cosubstrate regeneration. ${ }^{19}$ Though this latter approach seems attractive for 90 the development of highly sensitive hybridization assays, modest nanomolar detection limits of nucleic acids targets in solution have been reached to date with the glucose oxidase-HRP ${ }^{19 a}$ and glucose-6-phosphate deshydrogenase - diaphorase ${ }^{19 \mathrm{~b}}$ coupled 
systems. Recently, high amplification rates (> 1000) of the amperometric responses of aminophenolic products generated either by $\mathrm{AP}^{20}$ or by $\beta$-galactosidase ${ }^{21}$ enzyme labels were obtained either by adding the Diaphorase (DI) from Bacillus 5 stearothermophilus in the solution or by co-immobilizing the DI enzyme on the electrode surface, respectively. In such bienzymatic systems, the phenolic enzyme products can be oxidized at the electrode surface to give quinonimine derivatives according to a $-2 \mathrm{e}^{-}-2 \mathrm{H}^{+}$reaction. In the presence of the second 10 enzyme DI, the quinonimines are reduced back to aminophenols and the oxidized form of DI is finally regenerated in its reduced native state by its natural substrate, NADH.

The goal of the present work is to further extend the scope of this 15 bienzymatic electrochemical detection approach to the analysis of HCMV DNA hybridization. For such a purpose, we took advantage of our earlier optimized hybridization assay protocol involving easy-to-use disposable reproducible (relative standard deviation of $9 \%$ ) arrays of neutravidin-coated carbon screen20 printed sensors. ${ }^{11 \mathrm{c}}$ Briefly, the 406-base pair amplified HCMV DNA sequence targets were obtained by PCR amplification with biotinylated primers to produce biotinylated targets, which can be directly bounded to the neutravidin coated-electrodes, thus avoiding the use of an intermediary capture probe. The 25 immobilization of the DNA targets and their hybridization with digoxigenin-labeled detection probes were performed in a single step and followed by alkaline phosphatase labeling with an antidigoxigenin antibody conjugate (anti-Dig-AP). Alkaline phosphatase was selected as primary enzyme label in association 30 with the $p$-aminophenylphosphate (PAPP) $/ p$-aminophenol (PAP) substrate/product couple. The first part of this paper is devoted to the study of the analytical performances of the biosensor for the detection of an amplified viral DNA sequence with the AP label. Then, we will show how the amperometric response of AP, and 35 thus the sensitivity of the assay, can be further enhanced in the presence of DI enzyme.

\section{Experimental}

\section{Reagents and solutions}

${ }_{40}$ The 5'-biotinylated primers (Bio-AC1 and Bio-AC2) used to PCR-amplify the 406-bp HCMV target and the 5'-digoxigeninlabeled HCMV target specific detection probes (Dig- AC3, DigAC4, Dig-B1) were gift from Argene SA. All of these oligonucleotide sequences are the proprietary of Argene SA, as 45 well as the Hybridowell ${ }^{\circledR}$ kit which reagents (hybridization and washing buffers, ETS2 negative control) were used in this work. Taq polymerase, Taq polymerase buffer and the four nucleotide bases (dNTPs) were purchased from Qiagen (France). Low DNA Mass Ladder ${ }^{\circledR}$ for electrophoresis quantification was obtained 50 from Invitrogen (France).

Lyophilized Neutravidin ${ }^{\mathrm{TM}}$ and lyophilized biotinylated alkaline phosphatase (Bio-AP) were purchased from Pierce (USA). Lyophilized Fab fragments from anti-digoxigenin antibody from 55 sheep, conjugated with alkaline phosphatase (anti-Dig-AP) were obtained from Roche Diagnostics GmbH (Germany). Lyophilized Diaphorase (DI) from Bacillus stearothermophilus (E.C. 1.6.99.-) was provided from Unitika (Japan). NADH, Bovine Serum Albumine (BSA), tris-(hydroxymethyl)aminomethane (Tris), 60 magnesium chloride, ferrocenyl methanol, $p$ nitrophenylphosphate, and $\mathrm{NaBH}_{4}$ were supplied by Sigma-
Aldrich (France). Tween 20 was obtained from Prolabo (France). p-aminophenylphosphate (PAPP) was obtained by chemical reduction of p-nitrophenylphosphate with $\mathrm{NaBH}_{4}$ according to ${ }_{65}$ the protocol described in reference $22 .^{22}$

Phosphate-buffered saline (PBS; $4.3 \mathrm{mM} \mathrm{NaH}{ }_{2} \mathrm{PO}_{4}, 15.1 \mathrm{mM}$ $\mathrm{Na}_{2} \mathrm{HPO}_{4}$ and $50 \mathrm{mM} \mathrm{NaCl}$; $\mathrm{pH}$ 7.4), Tris buffer (TB; $0.1 \mathrm{M}$ Tris, 0.2 g. $\mathrm{L}^{-1} \mathrm{MgCl}_{2} ; \mathrm{pH} 8.5$ ) and all of the solutions were prepared 70 with water purified by an Elgastat water system (Elga, France). Stock solutions of $2 \mathrm{mM}$ PAPP and $8 \mathrm{mM}$ NADH were daily prepared in TB and stored at $4^{\circ} \mathrm{C}$. All reagents were of analytical grade and used without further purification.

\section{Instrumentation and electrochemical measurements}

${ }_{75}$ Cyclic voltammetry (CV) measurements were performed with an Autolab potentiostat (PGSTAT 12, Ecochemie) connected to a personal computer equipped with a GPES version 4.9 software. Disposable arrays of eight screen-printed carbon electrodes were prepared from a high impact polystyrene substrate (Sericol, ${ }_{80}$ Vaux-en-Velin, France) and a conductive carbon-based ink (Electrodag ${ }^{\circledR}$ PF 407A, Acheson Colloids) using a Presco screenprinting machine (USA). After a curing step, two insulating layers (Vinylfast 36-100, Argon) were printed over the array of eight electrodes, leaving uncovered sensing disk areas of $4.9 \mathrm{~mm}^{2}$ 85 and the electric contacts. The resulting ring-shaped layers around the working areas constituted the reservoirs for small-volume electrochemical biosensing cells. All the electrochemical measurements were carried out at room temperature in TB with a working volume of $20 \mu \mathrm{L}$ and involved an $\mathrm{Ag} / \mathrm{AgCl}$ wire 90 reference and a platinum wire counter electrodes.

\section{Preparation of the biosensing surfaces}

Unless otherwise stated, all the incubations were performed at room temperature in a water-saturated atmosphere. A drop of 20 ${ }_{95} \mu \mathrm{L}$ of a $0.5 \mathrm{mg} . \mathrm{mL}^{-1}$ saturating neutravidin solution in PBS was placed onto each working electrode surface and incubated for $2 \mathrm{~h}$. The surface of each sensor was then carefully rinsed with PBS to remove the excess of neutravidin and the array of sensors was dipped in a $20-\mathrm{mL}$ bath solution containing PBS with $0.1 \%(\mathrm{w} / \mathrm{v})$ 100 BSA (PBS-BSA) for $30 \mathrm{~min}$. After another thorough wash in a PBS bath, the resulting biosensing platform was stored in PBS at $4^{\circ} \mathrm{C}$ until used.

\section{HCMV DNA hybrization assay procedure}

${ }_{105}$ Unless otherwise stated, all the incubations were performed at $37^{\circ} \mathrm{C}$ in a water-saturated atmosphere. Each assay was performed onto the eight neutravidin-modified positions of the array using biotinylated target sequences according our previously reported protocol. ${ }^{11 \mathrm{c}}$

110 Briefly, HCMV DNA was extracted from cell culture, amplified by PCR using biotinylated primers, and then quantified by agarose gel electrophoresis. After purification and quantification, the double-stranded 406-bp DNA samples were thermally denaturated by heating for $20 \mathrm{~min}$ at $95^{\circ} \mathrm{C}$, diluted in the PCR 115 negative control with concentrations ranging from $10^{-15}$ to $10^{-7} \mathrm{M}$, then cooled in an iced bath. Meanwhile, complementary probes tagged with a digoxigenin label (Dig-B1, Dig-AC3 and DigAC4), were prepared at a final concentration of $1 \mu \mathrm{M}$ in the hybridization buffer and then mixed with the DNA sample $(1: 1$ $120 \mathrm{v} / \mathrm{v}) .20-\mu \mathrm{L}$ droplets of the resulting mixture were applied onto the active surface of the biosensor array and incubated for $1 \mathrm{~h}$. 
Each series of experiments included the analysis of a PCR negative control (containing all of the reagents, except DNA) and a noncomplementary DNA-amplified sequence (a human ETS2 DNA gene). After a washing cycle consisting of five rinses for 1 $5 \mathrm{~min}$ in a $20-\mathrm{mL}$ bath of fresh $1 \mathrm{X}$ washing solution, the active surfaces of the array were covered with drops of $20 \mu \mathrm{L}$ containing anti-Dig-AP (1/100 dilution in PBS-BSA containing $0.1 \%(\mathrm{v} / \mathrm{v})$ Tween 20$)$ and incubated at $37^{\circ} \mathrm{C}$ in a water-saturated atmosphere for $30 \mathrm{~min}$. A last washing cycle was then performed 10 with PBS-BSA containing $0.1 \%(\mathrm{v} / \mathrm{v})$ Tween 20 followed by PBS (five 20-mL bath for $1 \mathrm{~min}$ each with each buffer). Once carefully removed from the rinsing solution, the electrodes were stored in a $20-\mathrm{mL} \mathrm{TB}$ bath at $4^{\circ} \mathrm{C}$. The detection of the activity of the AP label and its amplification in the presence of DI were 15 carried out according to the following two protocols. 1) $20-\mu \mathrm{L}$ droplets of TB containing $1 \mathrm{mM}$ PAPP were deposited onto the surface of each sensor. After a 20-min enzyme incubation period, the generated PAP was determined by CV $\left(\mathrm{v}=10 \mathrm{mV} \cdot \mathrm{s}^{-1}\right)$ and the resulting anodic peak current $\left(i_{1}\right)$ at $\sim+0.25 \mathrm{~V}$ vs. $\mathrm{Ag} / \mathrm{AgCl}$ 20 was taken as the analytical response. 2) After a thorough rinse with $\mathrm{TB}$, the above AP detection procedure was then repeated with a $1 \mathrm{mM}$ PAPP mixture containing $2 \mathrm{mM}$ NADH and $50 \mathrm{nM}$ Diaphorase and the electrooxydation current response $\left(i_{2}\right)$ was measured on the $\mathrm{CV}$ curve $\left(\mathrm{v}=10 \mathrm{mV} \cdot \mathrm{s}^{-1}\right)$ at $+0.30 \mathrm{~V} v s$. ${ }_{25} \mathrm{Ag} / \mathrm{AgCl}$.

\section{Results and discussion}

\section{AP-based electrochemical hybridization assay of HCMV 30 DNA}

The main procedure for the detection of amplified HCMV DNA is illustrated in Fig. 1A.

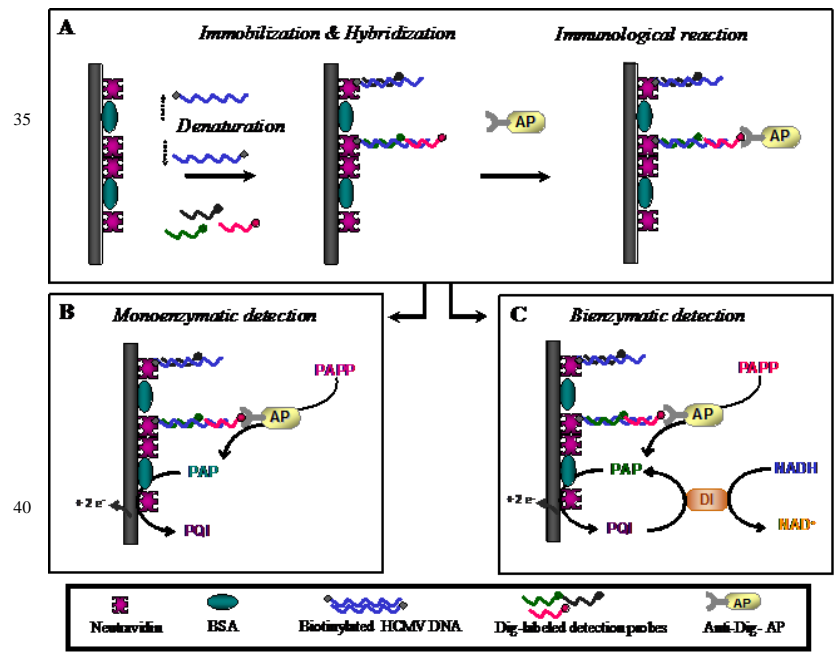

Fig. 1 Schematic representation of A) the AP-based hybridization assay of HCMV DNA on neutravidin-modified electrodes using B) a mono- or C) a bi-enzymatic electrochemical detection.

The immobilization of the biotinylated amplified 406-bp DNA 50 fragments onto SPEs covered with a monolayer of neutravidin and their hybridization with complementary digoxigenin-labeled oligonucleotide probes have been performed as described in a previous work. ${ }^{11 \mathrm{c}}$ The extent of hybrids formed was then determined by incubating an anti-digoxigenin AP conjugate 55 which optimal concentration was assessed in a series of preliminary experiments. Thereafter, as shown in Fig. 1B, the enzymatic reaction with the substrate PAPP deposited on the SPE surface was allowed to proceed and next the generated phenolic electroactive product was quantified by $\mathrm{CV}$. The magnitude of 60 the anodic peak current $\left(i_{1}\right)$, which corresponds to the oxidation of PAP into p-quinonimine (PQI) according to a $\left(2 \mathrm{e}^{-}+2 \mathrm{H}^{+}\right)$ reaction, is proportional to the amount of anti-Dig-AP anchored to the immobilized hybrids, and thus indirectly to the target DNA concentration initially present in the sample solution.

${ }_{65}$ A main and general problem encountered with AP-based assays is the substrate blank current generated in the absence of AP. The purity of the PAPP was thus first examined and a background current of $15 \pm 2.5 \mathrm{nA}$ corresponding to the residual traces of PAP contained in a $1 \mathrm{mM}$ TB solution of the synthesized PAPP 70 was recorded. The minimal detectable current in this study was thus equal to $23 \mathrm{nA}$ based on three times the standard deviation of the blank response. The sensitivity of the assay was investigated by varying the concentration of biotinylated amplified HCMV DNA products over the $10^{-15}-10^{-7} \mathrm{M}$ range and the corresponding 75 logarithmic standard plot (curve A) is shown in Fig. 2.

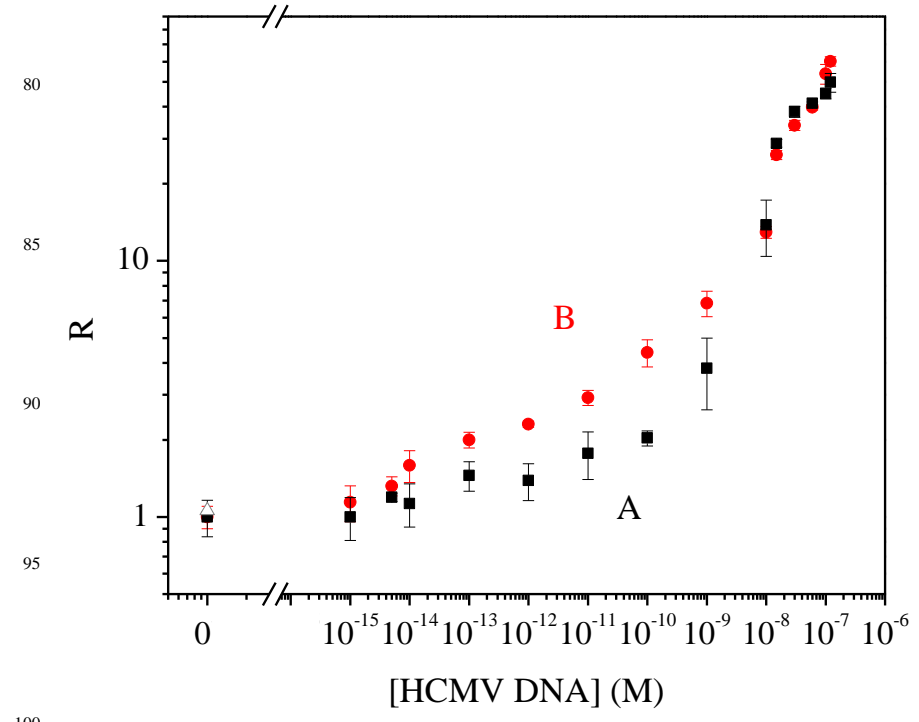

100

Fig. 2 Log-log calibration plots of HCMV DNA obtained for the hybridization procedure depicted in Fig. 1A using A) a mono- and B) a bi-enzymatic electrochemical detection. The $\mathrm{CV}$ responses were recorded at the SPEs after a 20-min incubation period in the presence of A) $1 \mathrm{mM}$ 105 PAPP and B) $2 \mathrm{mM} \mathrm{NADH}$ and $50 \mathrm{nM}$ DI in TB. The $\mathrm{R}$ values correspond to the current responses $i_{1}$ and $i_{2}$ normalized to the zero HCMV DNA concentration $\left(\mathrm{i}_{1}{ }^{0}=15 \mathrm{nA} ; \mathrm{i}_{2}{ }^{0}=100 \mathrm{nA}\right)$. The error bars represent the standard error of two electrochemical measurements. Open triangle symbol: control with a noncomplementary human ETS2 DNA 110 sequence.

With the aim to further compare the mono- and the bienzymatic approaches, the current responses $i_{1}$ was normalized to the blank response (sample which did not contain HCMV-amplified DNA fragments).The linearity range was extended over ca. 2 decades 115 (from 0.1 to $20 \mathrm{nM}$ HCMV DNA) and the signal saturated above $20 \mathrm{nM}$, owing to the limited amount of 406-bp HCMV DNA 
fragments immobilized onto the electrode surface i.e., one third of a packed monolayer according to our earlier estimation. ${ }^{11 \mathrm{c}} \mathrm{A}$ small baseline signal was recorded in the absence of HCMV DNA, thus indicating a very low nonspecific binding. The 5 selectivity of the assay was also confirmed since a negligible nonspecific response was obtained when replacing the HCMV DNA target with a noncomplementary biotinylated amplified human ETS2 fragment. Finally, a detection limit of $10 \mathrm{pM}(6 \times$ $10^{7}$ copies of HCMV-amplified DNA fragments per 10 electrochemical cell) could be estimated using a signal-to-noise ratio of $3(\mathrm{~S} / \mathrm{N}=3)$, which is 3 times lower than that previously obtained with the HRP label for the same assay format. ${ }^{11 \mathrm{c}}$ These results are in good agreement with the kinetic parameters of each label since the AP has a 4-fold higher turnover value for $\mathrm{PAPP}^{23}$ 15 than the HRP toward its osmium cosubstrate ${ }^{24}\left(\mathrm{k}_{\text {cat AP }}=1150 \mathrm{~s}^{-1}\right.$ and $\mathrm{k}_{\text {cat } \mathrm{HRP}}=280 \mathrm{~s}^{-1}$ ). Moreover, the HCMV DNA detection limit obtained in the present work competes favourably with other AP-based electrochemical DNA biosensors recently reported for the detection of PCR-amplified DNA products such 20 as GMO-related sequences $\left(1 \mathrm{nM}\right.$ or $6 \times 10^{9}$ copies of a $195 \mathrm{bp}$ region of the $35 \mathrm{~s}$ promoter), ${ }^{12 \mathrm{c}}$ Herpes simplex, Epstein-Barr and cytomegalovirus sequences of human viruses $\left(2 \mathrm{nM}\right.$ or $7.3 \times 10^{9}$ copies of viral DNA from a multiplexed PCR). ${ }^{12 \mathrm{~d}}$

\section{Amplification of the AP electrochemical hybridization 25 response with DI}

As sketched in Fig. 1C, the PAP generated by the immobilized AP label can be subsequently cycled in a redox reaction between PAP and PQI in the presence of the DI enzyme and its NADH substrate. The more practicable approach that consists in adding 30 the DI amplifier in solution was chosen in this work. In a set of preliminary experiments, neutravidin-coated electrodes covered with drops of a $10 \mu \mathrm{M}$ PAP and $2 \mathrm{mM} \mathrm{NADH}$ solution containing DI concentrations ranging from 0 to $1600 \mathrm{nM}$ were studied by cyclic voltammetry and the resulting curves are shown 35 in Fig. 3.

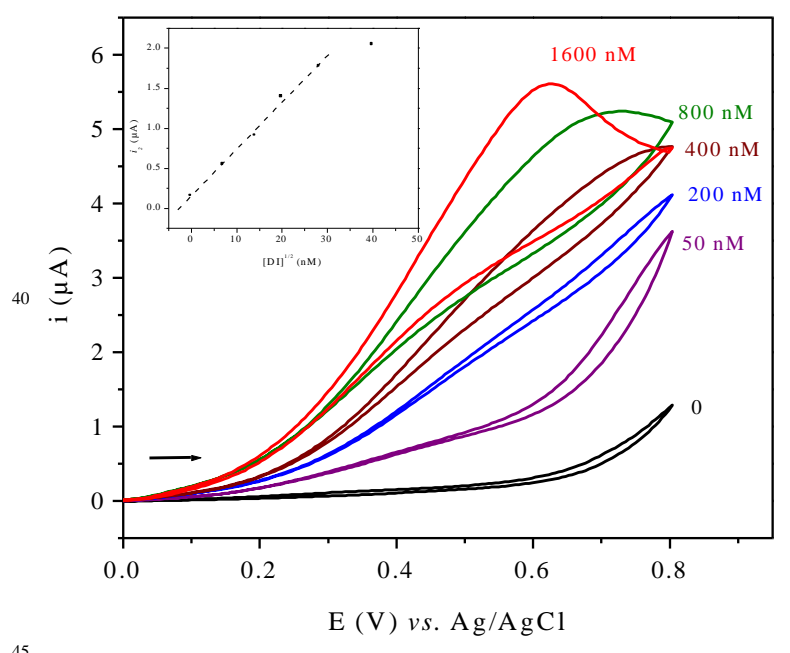

Fig. 3 Cyclic voltammetric curves $\left(v=10 \mathrm{mV} \cdot \mathrm{s}^{-1}\right)$ recorded at neutravidin-coated screen-printed electrodes as a function of the DI concentration in a TB solution containing $10 \mu \mathrm{M}$ PAP and $2 \mathrm{mM}$ NADH.

50 Inset: Variation of the catalytic current $\left(\mathrm{i}_{2}\right)$ with the square root of the DI concentration. Dashed line: linear fitting.
Instead of recording catalytic plateau shapes characteristic of steady-state conditions for low DI concentrations, bent catalytic waves are observed. Such behaviour can be explained by the 55 irreversibility of PAP at protein-covered screen-printed electrode surfaces - made of a random distribution of closely spaced insulating and conductive microscopic zones - combined with the contribution of the NADH electrochemical oxidation. At high DI concentrations, the progressive conversion of the pseudo plateau60 shaped to a peak-shaped response is indicative of the passage from control by the kinetic of the enzymatic reaction to control by substrate diffusion. Since the sensor response was not obvious to define, similar experiments were conducted with the reversible ferrocenyl methanol $(\mathrm{FcMeOH})$ cosubstrate to better assess the 65 electrochemical oxidation of NADH. Since its contribution has occurred just after $+0.3 \mathrm{~V}$, the electrocatalytic current value $i_{2}$ measured at $+0.3 \mathrm{~V}$ vs. $\mathrm{Ag} / \mathrm{AgCl}$ was selected as the analytical response. The linear variation of $\mathrm{i}_{2}-$ obtained under kinetic control- against the square root of the DI concentration (inset of ${ }_{70}$ Fig. 3) is in agreement with previously established results with the FcMeOH cosubstrate ${ }^{25}$ and clearly indicates that the PAP response, and thus the AP amplification rate, can be improved by raising the DI concentration in the solution.

${ }_{75}$ Consequently, the concept of using a DI auxiliary enzyme to amplify the amperometric response of the AP label was evaluated for the determination of HCMV DNA sequences in the hybridization assay reported in the previous section. For this purpose, a DI concentration of $50 \mathrm{nM}$ was selected since it 80 provided both an acceptable value for the blank signal $\left(i_{2}{ }^{0}=100\right.$ $\mathrm{nA}$ ) and a measurable amplification rate. The calibration plots obtained for the mono- (curve A) and the bi- (curve B) enzymatic detections over the $10^{-15}-10^{-7} \mathrm{M}$ HCMV DNA range are shown in Fig. 2. While both curves exhibited roughly the same signal 85 saturation shape above 10 nM HCMV DNA, no linearity range could be accurately defined when working with the bienzymatic system. Though the nonlinear shape of the curve B remained unexplained, the use of the DI enzyme amplifier significantly led to a wider working range $\left(10^{-12}-10^{-8} \mathrm{M}\right.$ instead of $\left.10^{-10}-10^{-8} \mathrm{M}\right)$ 90 and to a $\sim 10$-fold increase in sensitivity (calculated from the comparison of the slope of the two calibration plots using linear scales). A detection limit as low as $100 \mathrm{fM}$ could be estimated (6 $\times 10^{5}$ copies of HCMV-amplified DNA fragments per electrochemical cell), thus yielding a 100-fold improvement in 95 the detection limit of the AP-based HCMV DNA assay. To the best of our knowledge, the number of copies of DNA targets detected in the present work is roughly 160 times lower than those reported for other bienzymatic-based electrochemical hybridization assays. ${ }^{19}$

\section{${ }_{100}$ Conclusions}

The convenient use of arrays of screen-printed DNA biosensors in association with the electrochemical detection of the AP enzyme label with the PAPP substrate led to the specific and 105 sensitive detection of HCMV-amplified DNA. The obtained detection limit $\left(6 \times 10^{7}\right.$ copies of HCMV-amplified DNA fragments per electrochemical cell) is very competitive with other monoenzymatic electrochemical DNA sensors recently reported for the detection of PCR-amplified DNA products. ${ }^{12 \mathrm{c}, \mathrm{d}, 26}$

110

It has also been demonstrated that a greater level of sensitivity can be reached by amplifying the AP amperometric response with a DI auxiliary enzyme. This bienzymatic detection enabled a 100- 
fold lower HCMV DNA detection limit to be estimated. While the novel approach described in this work is promising, this detection limit is 700-fold higher than in our previous goldamplified electrochemical transduction of oligonucleotide 5 hybridization in polystyrene microwells with screen-printed microband electrodes (840 sequences per microwell). ${ }^{9 b}$ The length of the target (406 bp instead of $25 \mathrm{bp}$ ), the assay format (biosensor instead of microwell + microelectrode) are the main reasons to explain such differences. Hence, further improvements 10 are still required to detect as low as hundreds copies of target DNA per few tenths of microliters of sample with a bienzymatic system. This can be readily envisaged by co-immobilizing the DI enzyme on the electrode surface and/or using another aromatic monoester phosphate substrate with a very low level of residual 15 traces of phenol. ${ }^{21}$

\section{Acknowledgements}

The authors thank Argene SA for providing reagents and Region Bourgogne for financial support.

\section{${ }_{20}$ References}

1 (a) O. Lazcka, F.J. Del Campo and F.X. Munoz, Biosens. Bioelectron., 2007, 22, 1207-1217. (b) S. Cosnier and P. Mailley, Analyst, 2008, 133, 984-991.

2 D.M. Dankbar, E.D. Dawson, M. Mehlmann, C.L. Moore, J.A.

25 Smagala, M.W. Shaw, N.J. Cox, R.D. Kuchta and K.L Rowlen, Anal. Chem., 2007, 79, 2084-2090.

3 H.J. Lee, Y. Li, A.W. Wark amd R.M. Corn, Anal. Chem. 2005, 77, 5096-5100.

4 M. Minunni, S. Tombelli, J. Fonti, M.M. Spiriti, M. Mascini, P.

30 Bogani and M. Buiatti, J. Am. Chem. Soc., 2005, 127, 7966-7967.

5 T.G. Drummond, M.G. Hill and J.K Barton, Nat. Biotechnol., 2003, 21, 1192-1199.

6 A. Erdem, P. Papakonstantinou and H. Murphy, Anal. Chem., 2006, 78, 6656-6659.

357 K.M. Millan and S.R. Mikkelsen, Anal. Chem. 1993, 65, 2317-2323.

8 D.M. Jenkins, B. Chami, M. Kreuzer, G. Presting, A.M. Alvarez and B.Y. Liaw, Anal. Chem. 2006, 78, 2314-2318.

9 (a) L. Authier, C. Grossiord, B. Limoges and P. Brossier, Anal. Chem. 2001. 73, 4450-4456. (b) M. Rochelet-Dequaire, B. Limoges and P. Brossier, Analyst, 2006, 131, 923-929. (c) S. Pinijsuwan, P. Rijiravanich, M. Somasundrum and W. Surareungchai, Anal. Chem., 2008, 80, 6779-6784.

10 T. De Lumley-Woodyear, C.N. Campbell and A. Heller, J. Am. Chem. Soc., 1996, 118, 5504-5505.

4511 (a) F. Azek, C. Grossiord, M. Joannes, B. Limoges and P. Brossier, Anal. Biochem., 2000, 284, 107-113. (b) M. Dequaire and A. Heller, Anal. Chem., 2002, 74, 4370-4377. (c) N. Djellouli, M. RocheletDequaire, B. Limoges, M. Druet and P. Brossier, Biosens. Bioelectron., 2007, 22, 2906-2913. (d) A.L. Ghindilis, M.W. Smith,

$50 \quad$ K.R Schwartzkopf, K.M. Roth, K. Peyvan, S.B. Munro, M.J. Lodes, A.G. Stöver, K. Bernards, J. Dill and A. McShea, Biosens. Bioelectron., 2007. 22, 1853-1860.

12 (a) O. Bagel, C. Degrand, B. Limoges, M. Joannes, F. Azek and P. Brossier, Electroanalysis 2000, 18, 1447-1452. (b) Z.P. Aguilar and

55 I. Fritsch, Anal. Chem., 2003. 75, 3890-3897. (c) G. Carpani, F. Lucarelli, G. Marrazza and M. Mascini, Biosens. Bioelectron. 2004, 20, 167-175. (d) E. Nebling, T. Grunwald, J. Albers, P. Schäfer and R. Hintsche, Anal. Chem., 2004, 76, 689-696. (e ) D. HernandezSantos, M. Diaz-Gonzalez, M-B. Gonzalez-Garcia and A. CostaGarcia, Anal. Chem., 2004, 76, 6887-6893.

13 K. Ikebukuro, Y. Kohiki and K. Sode, Biosens. Bioelectron., 2002, 17, 1075-1080.

14 Y. Zhang, A. Pothukuchy, W. Shin, Y. Kim and A. Heller, Anal. Chem., 2004, 76, 4093-4097.

6515 S. Cosnier, R.E. Ionescu, S. Hermann, L. Bouffier, M. Demeunynck and R.S. Marks, Anal. Chem., 2006, 78, 7054-7057.
16 Y. Wang, M. Stanzel, W. Gumbrecht, M. Humenik and M. Sprintzl, Biosens. Bioelectron. 2007, 22, 1798-1806.

17 B. Munge, G. Liu, G. Collins and J. Wang, Anal. Chem., 2005, 77, $4662-4666$.

18 S. Hwang, E. Kim and J. Kwak, Anal. Chem., 2005, 77, 579-584.

19 (a) E. Dominguez, O. Rincon and A. Narvaez, Anal.Chem., 2004, 76, 3132-3138. (b) S. Sue, T. Matsura, T. Kimura, H. Zheng, T. Hori, Y. Amano and H. Katayama, Microelectron. Eng., 2005, 81, 441-447.

7520 B. Limoges, F. Mavré, D. Marchal and J-M. Savéant, J. Am. Chem. Soc., 2008, 130, 7276-7285.

21 B. Limoges, F. Mavré, D. Marchal and J-M. Savéant, J. Am. Chem. Soc., 2006, 128, 6014-6015.

22 R.Q. Thompson, C.G. Barone III, H.B. Halsall and W.R. Heineman, Anal. Biochem., 1991, 192, 90-95.

23 B. Limoges, F. Mavré, D. Marchal and J-M. Savéant, J. Am. Chem. Soc., 2008, 130, 7259-7275.

24 B. Limoges, J-M. Savéant and D. Yazidi, J. Am. Chem. Soc., 2003, 125, 9192-9203.

8525 B. Limoges, F. Mavré, D. Marchal and J-M. Savéant, J. Am. Chem. Soc., 2006, 128, 2084-2092.

26 (a) A. Lermo, S. Campoy, J. Barbé, S. Hernández, S. Alegret and M.I. Pividori, Biosens. Bioelectron., 2007, 22, 2010-2017. (b) A. Lermo, E. Zacco, J. Barak, M. Delwiche, S. Campoy, J. Barbé, S.

90 Hernández, S. Alegret and M.I. Pividori, Biosens. Bioelectron., 2008, 23, 1805-1811. (c) M. Wojciechowski, R. Sundseth, M. Moreno and R. Henkens, Clin. Chem., 1999, 45, 1690-1693. 